\title{
Evaluating Raw and Treated Water Quality of Tigris River within Baghdad by Index Analysis
}

\author{
Abdul Hameed M. Jawad Alobaidy ${ }^{1}$, Bahram K. Maulood ${ }^{2}$, Abass J. Kadhem ${ }^{1}$ \\ ${ }^{1}$ Environmental Research Center, University of Technology, Baghdad, Iraq \\ ${ }^{2}$ Twin Rivers Institute, American University of Iraq-Sulaimani, Sulaimani, Iraq \\ E-mail:jawaddhy@yahoo.co.in,Bahram.Khider@auis.org,aik_mik@yahoo.com \\ Received April 1, 2010; revised May 12, 2010; accepted May 24, 2010
}

\begin{abstract}
A water quality index (WQI) is a single value indicator of the water quality determined through summarizing multiple parameters of water test results into simple terms for management and decission makers. In this paper, thirteen parameters were considered. On the basis of these data, raw and treated drinking water from Tigris River within Baghdad were analyzed. Cluster analysis conducted on the WQI data in this area was applied to detect the fluctuation of water quality. In this study, WQI showed that Tigris water never reached "Excellent" levels nor fallen to "Unsuitable" condition, except in occasional untreated water samples. Effects of various sources of pollution were evident and the needs for intensive studies on WQI became evident.
\end{abstract}

Keywords: Water Quality Index, Tigris River, Drinking Water, Nature Iraq

\section{Introduction}

Globally, there is an increasing awareness that water will be one of the most critical natural resources in future. Water scarcity is increasing worldwide and pressure on the existing water recourses is increasing due to the growing demands in several sectors such as, domestic, industrial, agriculture, hydropower generation, etc. Therefore, the evaluation of water quality in various countries has become a critical research topic in the recent years [1].

The quality of water is defined in terms of its physical, chemical and biological parameters, and ascertaining its quality is important before use for various intended purposes such as potable, agricultural, recreational and industrial water usages, etc. [2]. It is assessed with the help of various parameters to indicate their pollution level. It is quite likely that any sample of water will exhibit various levels of contamination with respect to the different parameters tested [3].

In monitoring programs, generally relevant chemical, physical, and biological factors are annually (or with less intervals) sampled and analyzed to sort out governing factors for the water quality variations. Generally, such monitoring gives a clue about the status of water quality that might be valid for a limited time and pre-specified objectives. However, these data may not give the indica- tion of trends in water quality over time and across geographic areas. Traditional approaches to assessing water quality are frequently based on a comparison of experimentally determined parameter values with existing guidelines. In many cases, monitoring allows proper identification of contamination sources and may face legal compliance. However, it does not easily give an overall vision of the spatial and temporal trends in the overall water quality in a watershed [4]. Many attempts were made to present the water quality data in understandable and acceptable ways using the water quality index (WQI) [5].

WQI is an arithmetical tool used to transform large quantities of water quality data into a single cumulatively derived number. It represents a certain level of water quality while eliminating the subjective assessments of such quality [5-7]. It is intended as a simple, readily understandable tool for managers and decision makers to convey information on the quality and potential uses of a given water body, based on various criteria [6]. Furthermore it turns complex water quality data into information that is understandable and usable by the public. It gives the public a general idea of the water quality in a particular region.

The advantage of this approach, besides getting the information and data necessary, is also determined the general health or status of the system of concern. In this 
way, the index can be used to assess water quality relative to its desirable state (as defined by water quality objectives) and to provide insight into the degree to which water quality is affected by human activity [8].

To summarize the vast amount of analytical data regarding water quality into useful, easy to understand and convenient management tools for the assessment of water quality, the concept of WQI was developed and proposed first by Horten [9]. It is a single number like a grade that expresses the overall water quality at a certain area and time based on several water quality parameters. It is also defined as a rating reflecting a composite influence, on overall quality of water, of a number of water quality parameters. WQI value makes information more easily and rapidly understood rather than a long list of numerical values for a large variety of parameters. Additionally, WQI's also facilitate comparison between different sampling sites and/or events. Thus, they are considered better for transmitting information to general audiences [6]. When their specific characteristics and limitations are considered [10-12], WQI's can be quite useful for the purpose of management and decisionmaking. Nevertheless, many different methods for the calculation of WQI's have been developed. In general, they all consider similar physical and chemical parameters but differ in the way the parameter values are statistically integrated and interpreted [5].

Water quality indices are generally calculated in two steps. The selected water quality characteristics having different units of measurement are transformed into sub index values. These sub indices are then aggregated to give a water quality index value. Various water quality indices were reviewed by many researchers; [5,7,10-20]. WQI approach has been applied in many countries to assess the overall status of their water bodies, such as United States [21], United Kingdom [22], Canada [23], India [24] and Egypt [25]. The concept is similar, where a few important parameters are selected and compounded into numerical rating for the evaluation of the water quality. However, in Iraq such studies are in a preliminary stage or not existing, therefore this paper may be regarded as the first attempt to be applied in this country that possibly will lead to several investigations in the future. The present study is a part of Nature Iraq Indices Project undertaken to highlight the physico-chemical drinking water quality index and the status of Tigris River water quality which have been used as raw water for the Water Treatment Plant (WTPs) within Baghdad, the capital of Iraq.

\section{Materials and Methods}

\subsection{Study Area}

The study area (Tigris River within Baghdad City) is located in the Mesopotamian alluvial plain between lati- tudes $33^{\circ} 14^{\prime}-33^{\circ} 25^{\prime} \mathrm{N}$ and longitudes $44^{\circ} 31^{\prime}-44^{\circ} 17^{\prime} \mathrm{E}$, 30.5 to $34.85 \mathrm{~m}$ a.s.l. The River divides the city into a right (Karkh) and left (Risafa) sections with a flow direction from north to south. The area is characterized by arid to semi arid climate with dry hot summers and cold winters; the mean annual rainfall is about $151.8 \mathrm{~mm}$ [26].

\subsection{Application of the WQI}

The data used in this paper were provided by Baghdad Mayoralty (Amanat Baghdad) and cover the period from February 2002 to December 2008. Raw water samples were collected using clean polyethylene containers from sites in the river just close to the WTPs that represent the stations of this study. While treated water samples were collected from the treatment plants just before the distribution of potable water to the houses through the water supply network. Samples were analyzed for chemical and physical properties immediately after collection. The data were merged (monthly average values for each parameters) to obtain a data set covering seven years of data for seven raw (Tigris river before treatment) and seven drinking water (after treatment) stations, (Figure 1). For calculating the Water Quality Index, a set of thirteen water quality parameters have been selected based on both importance of the parameters and availability of data. These thirteen parameters are $\mathrm{pH}$ value, Alkalinity, Turbidity, Total Dissolved Solids, Hardness, Calcium, Magnesium, Chloride, Sulphate, Ammonia, Fluoride, Iron and Aluminum.

\subsection{Calculations of the WQI}

For calculating WQI, the following steps were used:

In the first step, unit weight $\left(W_{i}\right)$ for various parameters is inversely proportional to the recommended standard $\left(V_{\text {standard }}\right)$ for the corresponding parameter. $W_{i}$ values were calculated by using the following formula proposed by Tiwari and Mishra [24],

$$
W_{i}=\frac{K}{V_{\text {standard }}}
$$

where, $K=$ proportionality constant, $V_{\text {Standard }}=$ worldwidely accepted drinking water quality standard prescribed by WHO [27].

The constant of proportionality $K$ in the above equation can be determined from the following condition,

$$
\sum W_{i}=K \Sigma\left(\frac{1}{V_{\text {standard }}}\right)
$$

In the second step, Quality rating $\left(Q_{i}\right)$ is calculated as,

$$
Q_{i}=100\left[\frac{V_{\text {actual }}}{V_{\text {standard }}}\right]
$$


While, the quality rating for $\mathrm{pH}\left(Q_{p H}\right)$ was calculated on the basis of,

$$
Q_{p H}=100\left[\frac{\left(V_{\text {actual }}-V_{\text {ideal }}\right)}{\left(V_{\text {standard }}-V_{\text {ideal }}\right)}\right]
$$

where, $V_{\text {actual }}=$ value of the water quality parameter obtained from the laboratory analysis.

$V_{\text {ideal }}=$ the ideal value of $\mathrm{pH}$ considered as equal to (7.00).

$V_{\text {standard }}=$ value of the water quality parameter obtained from recommended WHO standard of corresponding parameter.

This equation ensures that $Q_{i}=0$ when a pollutant is totally absent in the water sample and $Q_{i}=100$ when the value of this parameter is just equal to its permissible value. Thus the higher the value of $Q_{i}$ is, the more polluted is the water.

Then, the overall WQI was calculated using the method proposed by Ott [10] and Harkins [28] on the basis of weighting and rating of the different physico-chemical parameters, as follows:

$$
W Q I=\sum_{i=1}^{i=n} W_{i} Q_{i}
$$

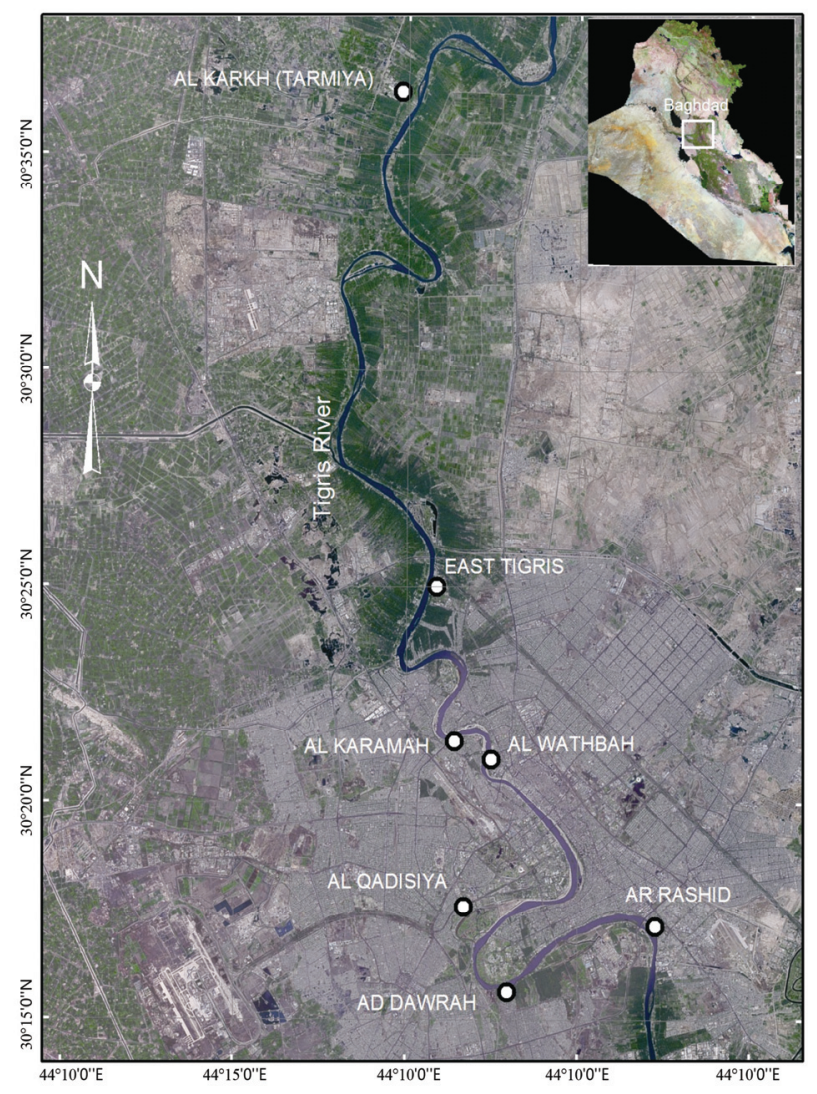

Figure 1. Sampling locations across Tigris River, Baghdad City.
Based on the calculated WQI, the classification of water quality types is given according to [24] as shown in Table 1.

\subsection{Quality Rating and Weighting}

Water quality parameters were studied in respect to their suitability for human consumption. The 'standards' (permissible values of various pollutants) for the drinking water, recommended by the World Health Organization [27], and unit weights are given in Table 2.

\section{Results and Discussion}

\subsection{Annual WQI}

Applying the former equations on the results of water analysis data of Tigris River, annual WQI (Raw and Treated) have been plotted in Figure 2. Spatial profiles of the results showed that, for raw water, none of the samples are coming neither under "Excellent" (range $0-25$ ) nor "Good" (range 26-50) water quality, indicating that the Tigris River water is generally "Poor" (range 51-75) at the upstream and is either "Poor", "Very poor" (range 75-100) or "Unsuitable" (above 100) at the mid and downstream. This may reflect the effect of pollution from urban wastes and anthropogenic activities. On temporal basis, the WQI values for raw water for all sites were highly increased in the last three years (2006-2008).

Table 1. Water quality index scale.

\begin{tabular}{llllll}
\hline WQI & $0-25$ & $26-50$ & $51-75$ & $76-100$ & $>100$ \\
\hline $\begin{array}{l}\text { Water } \\
\text { quality }\end{array}$ & $\begin{array}{l}\text { Excel- } \\
\text { lent }\end{array}$ & Good & Poor & $\begin{array}{l}\text { Very } \\
\text { poor }\end{array}$ & $\begin{array}{l}\text { Unsuit- } \\
\text { able }\end{array}$ \\
\hline
\end{tabular}

Table 2. Drinking water standards and unit weights.

\begin{tabular}{lcc}
\hline Water quality parameters & Standards & $\begin{array}{c}\text { Unit Weights } \\
\left(W_{\mathrm{n}}\right)\end{array}$ \\
\hline $\mathrm{pH}$ value (pH unit) & $6.5-8.5$ & 0.007990 \\
Alkalinity (mg/L) & 100 & 0.000679 \\
Turbidity $(\mathrm{NTU})$ & 5.0 & 0.013583 \\
Dissolved Solids $(\mathrm{mg} / \mathrm{L})$ & 500 & 0.000136 \\
Hardness $(\mathrm{mg} / \mathrm{L})$ & 100 & 0.000679 \\
Calcium $(\mathrm{mg} / \mathrm{L})$ & 100 & 0.000679 \\
Magnesium $(\mathrm{mg} / \mathrm{L})$ & 30 & 0.002264 \\
Chloride $(\mathrm{mg} / \mathrm{L})$ & 250 & 0.000272 \\
Sulphate $(\mathrm{mg} / \mathrm{L})$ & 250 & 0.000272 \\
Ammonia $(\mathrm{mg} / \mathrm{L})$ & 0.2 & 0.339574 \\
Fluoride $(\mathrm{mg} / \mathrm{L})$ & 1.0 & 0.067915 \\
Iron $(\mathrm{mg} / \mathrm{L})$ & 0.3 & 0.226383 \\
Aluminum $(\mathrm{mg} / \mathrm{L})$ & 0.2 & 0.339574 \\
\hline
\end{tabular}


The effect of dryness in the area in the last three years might be behind the clearly observed depletion of WQI throughout this period, especially in the upstream stations where there is no high intervention between the effects of dryness and those of human activities.

Nevertheless, for spatial profiles of treated water, none of the samples are classified as "Excellent" or "Unsuitable". The results showed "Poor" to "Good" quality in all stations. As for temporal trend, water quality was generally "Good" at the upstream throughout the study period (WQI range: 25.24-43.11) for AL KARKH and EAST TIGRIS WTPs. With few exceptions the results of WQI showed generally "Poor" but not "Unsuitable" quality at the midstream and downstream. This might be due to increasing pollution of raw water from urban wastes and anthropogenic activities [20]. Generally, the peak year of degradation of water quality was 2008 in all stations.

For both raw and treated water, the phenomenon of water quality degradation along Tigris was generally evident throughout the seven years results. Therefore, the authorities should practice more efforts in controlling various activities along the river bank. The urgent water management rules should be applied, enforcing wastewater treatment systems among the factories and other activities.
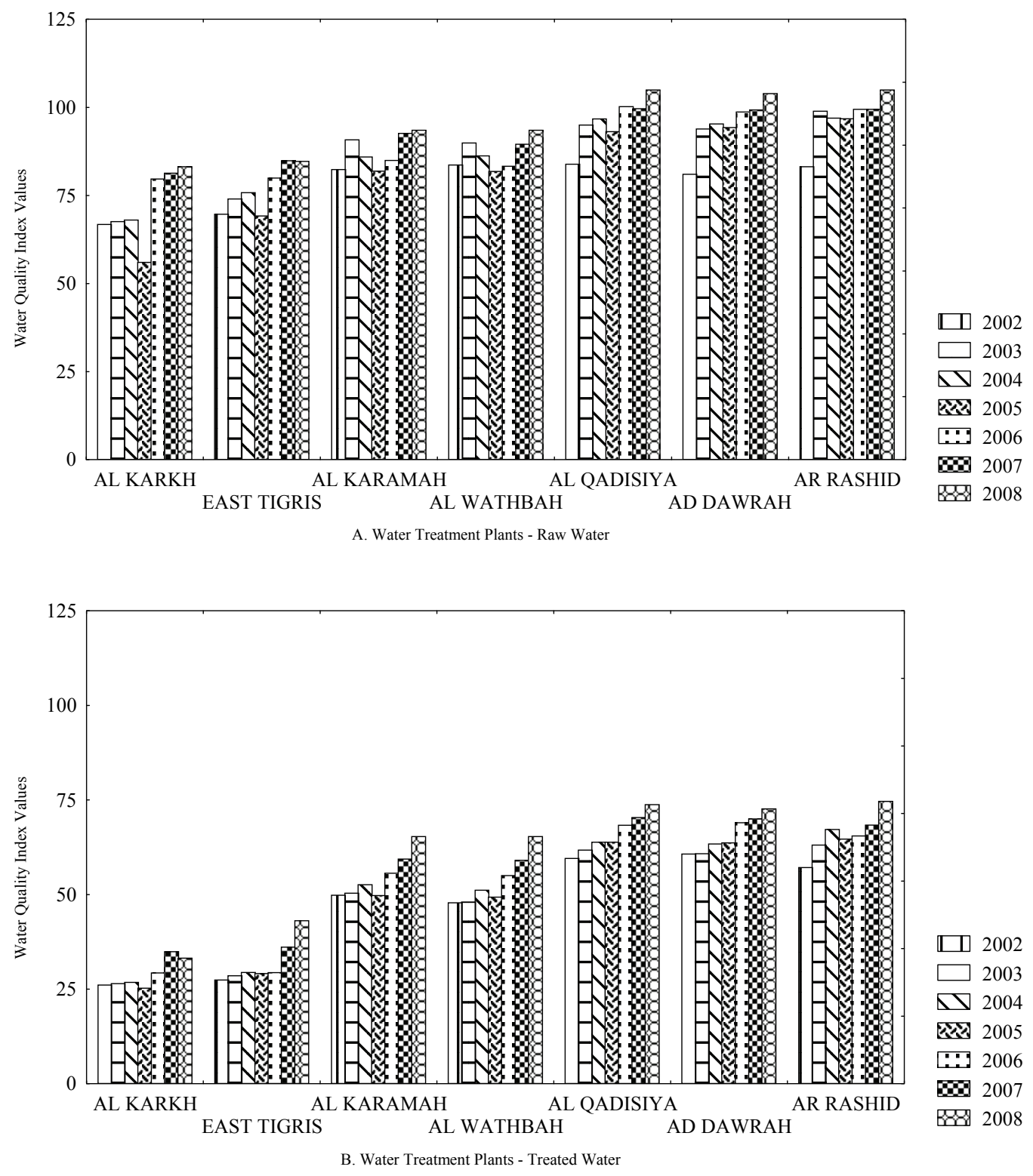

Figure 2. Annual water quality index. 


\subsection{Cluster Analysis}

Cluster analysis was applied to find different classes (sub clusters) within the WQI data that might help us to show how the water quality is affected by the course of the river through the city. The raw and treated WQI data for all sites was processed by SPSS statistical software. The cluster analysis was carried out on the data applying Ward's method, using Squared Euclidean Distance as a measure of similarity. Ward's hierarchical clustering method was chosen for this purpose as it aims to minimize the loss of information at each step in the clustering process [29].

The results of cluster analysis for WQI of raw water are illustrated with a tree dendrogram (Figure 3). It is clear that WQI results divided the stations on Tigris into three separate sub clusters: AL KARKH (TARMIYA) at upstream, EAST TIGRIS, ALWATHBAH and ALKARAMAH at midstream, and AR RASHID, ALQADISIYA and AD DAWRAH at downstream. WQI values of raw water deteriorated from "Poor" to "Very poor" to "Unsuitable" along the stretch of the river. However, the major reasons of deteriorating water quality are the discharge from drainage tributaries, city wastewater and other forms of intensives human activities which are increasing in trend from north to south. This comes in accordance with the findings of Fulazzaky [20] and Ouyang [30] who referred to these factors as main reasons for deteriorated water quality.

The results of cluster analysis of WQI for treated water were distributed in three sub clusters as illustrated with a tree dendrogram (Figure 4). The first sub-cluster gathers AL KARKH and EAST TIGRIS WTPs, with WQI values reflecting "Good" to "Poor" water. While, ALKARAMAH and AL WATHBAH WTPs were in a second sub-cluster and AD DAWRAH, AR RASHID and AL QADISIYA WTPs were in a third sub cluster. Water quality for both of these sub clusters was "Poor" in general.

It is very important to establish an index showing the information of the river water quality and providing the warning alarm to take pollution control actions. This investigation might be regarded as a pioneer attempt for water quality indices in Baghdad as well as whole Iraq in general. Undoubtedly, this may lead to more intensive detailed studies on WQI in the area in order to fulfil the existing gap of information about this subject in Iraq. The results indicate the need for more consideration of the WTPs along Tigris for years to come.

\subsection{Efficiency of the Water Treatment Plants}

Efficiency $(E \%)$ of the Water Treatment Plants situated at Tigris River was calculated by determining the WQI of the raw water and treated (Tap) water supplied by using the formula given below:

$$
E \%=\frac{W Q I \text { of raw water }- \text { WQI of treated water }}{\text { WQI of raw water }} \times 100
$$

The water treatment plants of Baghdad Mayoralty have a capacity to treat 2,272,100 cubic meters per day of raw water pumped from Tigris River, from which $2,082,000$ cubic meters of water is supplied. The water treatment plants follow the traditional treatment process, in which raw water after aeration is treated with coagulant (alum and lime) and pre-chlorination as required. After flocculation, it is carried over to the sand bed filter for filtration. After this, bleaching powder or chlorine gas is added for disinfection to ensure the Residual Chlorine at the tail end is in the range of 0.2 to $0.5 \mathrm{mg} / \mathrm{L}$.

Table 3 represents the efficiency of the water treatment plant situated at Baghdad City. From Table 3 it has been concluded that the raw water is poorest in quality throughout the year as the efficiency of WTPs range from 25.07 to 63.30 in the whole period of study. Ultimately, reconsideration of the WTPs system is needed since these stations were designed to provide physical and biological treatment rather than chemical treatment of raw water. This will surely have more consequences if combined with the already high levels of chemical pollution of raw water that we have shown in our results above. Strict measures should be applied in order to control the levels of pollutants discharged into Tigris from different kinds of point and nonpoint sources.

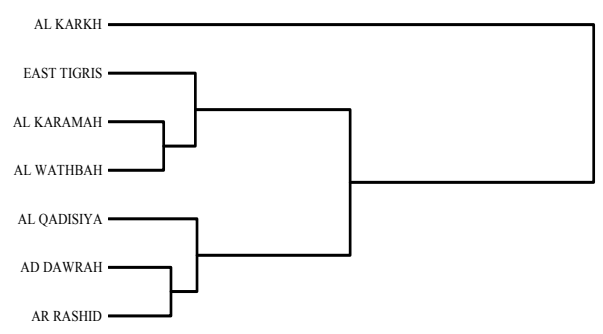

Figure 3. Dendrogram obtained using ward's method for raw water quality index.

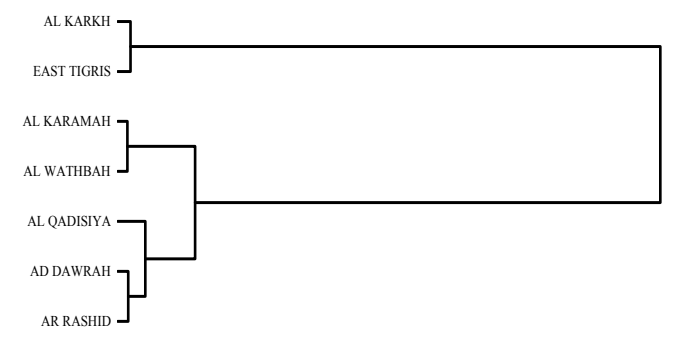

Figure 4. Dendrogram obtained using ward's method for treated water quality index. 
Table 3. Efficiency of the water treatment plants.

\begin{tabular}{llllllll}
\hline \multirow{2}{*}{ WTPs } & \multicolumn{7}{c}{ Efficiency\% } \\
\cline { 2 - 8 } & 2002 & 2003 & 2004 & 2005 & 2006 & 2007 & 2008 \\
\hline AL KARKH & 60.97 & 60.86 & 60.57 & 54.93 & 63.20 & 57.07 & 60.06 \\
EAST TIGRIS & 60.62 & 61.45 & 61.19 & 57.86 & 63.30 & 57.43 & 49.08 \\
AL KARAMAH & 39.47 & 44.52 & 38.79 & 39.30 & 34.50 & 35.87 & 30.14 \\
AL WATHBAH & 42.85 & 46.56 & 40.69 & 39.67 & 33.87 & 34.07 & 30.17 \\
AL QADISIYA & 29.03 & 34.96 & 33.99 & 31.46 & 31.86 & 29.36 & 29.69 \\
AD DAWRAH & 25.07 & 35.22 & 33.49 & 32.47 & 30.10 & 29.52 & 30.07 \\
AR RASHID & 31.26 & 36.22 & 30.66 & 33.18 & 34.16 & 31.26 & 28.84 \\
\hline
\end{tabular}

\section{Acknowledgements}

Many thanks to Nature Iraq, without their support and encouragement the work would have not been done. Our special gratitude is forwarded to "Nature Iraq Indices" project manager Mr. Haider Abid for his efforts. However, our thanks are also extended to Baghdad Mayoralty for supplying the raw data.

\section{References}

[1] E. D. Ongley, "Modernization of Water Quality Programs in Developing Countries Issues of Relevancy and Cost Efficiency," Water Quality International, September -October 1998, pp. 37-42.

[2] A. Sargaonkar and V. Deshpande, "Development of an Overall Index of Pollution for Surface Water Based on a General Classification Scheme in Indian Context," Environmental Monitoring and Assessment, Vol. 89, No. 1, 2003, pp. 43-67.

[3] S. A. Abbasi, "Water Quality Indices: State-of-the-Art," Centre for Pollution Control \& Energy Technology, Pondicherry University, Pondicherry, 1999.

[4] P. Debels, R. Figueroa, R. Urrutia, R. Barra and X. Niell, "Evaluation of Water Quality in the Chilla'n River (Central Chile) Using Physicochemical Parameters and a Modified Water Quality Index," Environmental Monitoring and Assessment, Vol. 110, No. 1/3, 2005, pp. 301322.

[5] N. Štambuk-Giljanović, "Water Quality Evaluation by Index in Dalmatia," Water Research, Vol. 33, No. 16, 1999, pp. 3423-3440.

[6] N. Štambuk-Giljanović, "Comparison of Dalmatian Water Evaluation Indices," Water Environment Research, Vol. 75, No. 5, 2003, pp. 388-405.

[7] W. W. Miller, H. M. Joung, C. N. Mahannah and J. R. Garrett, "Identification of Water Quality Differences in Nevada through Index Application," Journal of Environmental Quality, Vol. 15, 1986, pp. 265-272.

[8] N. Radwn, "Evaluation of Different Water Quality Parameters for the Nile River and the Different Drains," 9th International Water Technology Conference, Sharm
El-Sheikh, Egypt, 2005.

[9] R. K. Horton, "An Index Number System for Rating Water Quality," Journal of Water Pollution Control Federation, Vol. 37, No. 3, 1965, pp. 300-306.

[10] W. R. Ott, "Environmental Indices: Theory and Practice," Ann Arbor Science Publishers Inc., Ann Arbor, Michigan, USA, 1978.

[11] D. Hallock, "A Water Quality Index for Ecology's Stream Monitoring Program," Technical Report, Washington Department of Ecology, Environmental Assessment Program, Olympia, 2002.

[12] S. F. Pesce and D. A. Wunderlin, "Use of Water Quality Indices to Verify the Impact of Córdoba City (Argentina) on Suquìa River," Water Research, Vol. 34, No. 11, 2000, pp. 2915-2926.

[13] R. M. Brown, N. I. McClelland, R. A. Deininger and R. G. Tozer “A Water Quality Index: Do We Dare?” Water Sewage Works, Vol. 117, No. 10, 1970, pp. 339-343.

[14] A. A. Bordalo, W. Nilsumranchit and K. Chalermwat, "Water Quality and Uses of the Bangpakonk River (Eastern Thailand)," Water Research, Vol. 35, No. 15, 2001, pp. 3635-3642.

[15] C. Cude, "Oregon Water Quality Index: A Tool for Evaluating Water Quality Management Effectiveness," Journal of American Water Resource Association, Vol. 37, No. 1, 2001, pp. 125-137.

[16] S. M. Liou, S. L. Lo and S. H. Wang, "A Generalized Water Quality Index for Taiwan," Environmental Monitoring and Assessment, Vol. 96, No. 1-3, 2004, pp. 35-52.

[17] M. N. El-Gafy, A. Faria, A. El-Bahrawy, A. Khalifa, E. El-Basiony and M. Abdelmotaleb, "Decision Support System for Evaluation the Groundwater Quality," Emirates Journal for Engineering Research," Vol. 10, No. 1, 2005, pp. 69-78.

[18] D. K. Sinha and A. Saxena, "Statistical Assessment of Underground Drinking Water Contamination and Effect of Monsoon at Hasanpur, J.P.Nagar (Uttar Pradesh, India)," Journal of Environmental Science and Engineering, Vol. 48, No. 3, 2006, pp. 157-164.

[19] S. E. Gómez, R. C. Menni, J. G. Naya and L. Ramirez, "The Physical-Chemical Habitat of the Buenos Aires Pejerrey, Odontesthes bonariensis (Teleostei, Atherinopsi- 
dae), with a Proposal of a Water Quality Index," Environmental Biology of Fishes, Vol. 78, No. 2, 2007, pp. 161-171.

[20] M. A. Fulazzaky, "Water Quality Evaluation System to Assess the Brantas River Water," Water Resource Management, Vol. 23, No. 14, 2009, pp. 3019-3033.

[21] L. W. Canter, "Environmental Impact Assessment," 2nd Edition, McGraw-Hill Inc., New York, USA, 1996.

[22] M. A. House, "A Water Quality Index for River Management," Water and Environment Journal, Vol. 3, No. 4, 1989, pp. 336-344.

[23] Canadian Council of Ministries of the Environment (CCMC), "Canadian Water Quality Index 1.0 Technical Report and User's Manual," Canadian Environmental Quality Guidelines, Technical Subcommittee, Gatineau, 2001.

[24] T. N. Tiwari and M. Mishra, "A Preliminary Assignment of Water Quality Index of Major Indian Rivers," Indian Journal of Environmental Protection, Vol. 5, No. 4, 1985, pp. 276-279.
[25] UNEP "Development of Water Quality Indices for Sustainable Development: A Case Study," Proceeding of the Expert Group Meeting on the Implication of Agenda Region, Amman, 2-5 October 1995.

[26] A. S. Al-Adili, "Geotechnical Evaluation of Baghdad Soil Subsidence and their Treatments," Ph.D. Thesis, University of Baghdad, Iraq, 1998.

[27] World Health Organization (WHO), "Guidelines for Drinking Water Quality," 3rd Edition, Geneva, 2004.

[28] R. D. Harkins, "An Objective Water Quality Index," Journal of Water Pollution Control Federation, Vol. 46, No. 5, 1974, pp. 588-591.

[29] J. H. Ward, "Hierarchical Grouping to Optimize an Objective Function," Journal of the American Statistical Association, Vol. 58, No. 301, 1963, pp. 236-244.

[30] T. Ouyang, Z. Zhu and Y. Kuang, “Assessing Impact of Urbanization on River Water Quality in the Pearl River Delta Economic Zone, China," Environmental Monitoring and Assessment, Vol. 120, No. 1-3, 2006, pp. 313325 . 